\title{
Female Readers as Literary Critics: Reading Experiences of Kano Market Romance Fiction
}

\section{Haruna Alkasim Kiyawa}

\begin{abstract}
This paper aims to explore the female readers reading experiences, views and feelings of Hausa romance novels found in most of the northern part of Nigeria. This article also examines some criticism and accusations against the readership and content of the Hausa romance genre. The study applied the Transactional Reader-Response Theory of Rosenblatt's (1978) as guide by selecting 7 female readers within the age ranges between 22-26 years from 2 book clubs to participate in the study. The findings revealed that all the readers individually were able to reveal their varied responses, beliefs, and experiences on the value of the romance novels which challenged the assertion made by the literary critics and traditional society that the books have no relevance in their life activities which supported their arguments and personal interpretive reading stance towards the Hausa romance genre. The finding yielded four themes were emerging: (a) promoting literacy development; (b) resistance to the traditional marriage system in society; (d) enlightening females on social inequality. These findings provided empirical support for the application of the Transactional Reader-Response Theory of Rosenblatt (1978) outside classroom contexts to understand the role of African romance novels towards female social transformation.
\end{abstract}

\section{Keywords}

Kano Market Romance novels, Female Readers clubs, Interviews, ReaderResponse Criticism. 



\title{
Female Readers as Literary Critics: Reading Experiences of Kano Market Romance Fiction
}

\author{
Haruna Alkasim Kiyawa
}

\section{Introduction}

Hausa romance novel is a literary phenomenon referred to as Kano Market Literature (KML). It was over twenty-five years ago after the introduction of universal primary basic education for all by the federal government under the military regime in 1970 which increased the number of literate young people looking for reading material from their native language contributed immensely to the development of Hausa writers' clubs (Furniss 14; Malumfashi 440). One major reason in the development of the Hausa literary writing was the introduction of many Hausa listeners, radio programs that broadcast readings of love story manuscripts/romance novels written by the youth both male and females. Most of the radio stations are owned by the federal/state government in the northern part of Nigeria, such as Kaduna, Kano, Jigawa, Bauchi and Sokoto. Generally, all their programs aired daily for at least 20-30 minutes on Saturdays and Sundays or twice in a week to entertain their listeners. After the program, the presenter will announce the names of new novels, which is seen as an advertisement that motivates many listeners would go to the nearby book shops and open market to buy and read. The romance literary writing was originated and started around 1984 in Kano state which has been the center of commerce, trade and business within the Hausa speaking community's region of North-Western part of Nigeria. It was also observed that most of private owned publishing companies were established and printing thousand copies distributed within the towns and cities of the country (Larkin 440; Adamu and Furniss; 111; Malami 109).

Kano is one of the most famous densely populated cities of the northern part of Nigeria. Therefore, people also coming for the purpose of buying and selling different type of commodities, in addition, the covers of these romance fiction carried many images/designs for instance, beautiful women images, rings, flashy cars, river bank, luxurious houses and others which increase the reading motivation in the hearts of almost all female readers and it attract the attention of publishers' production and distribution of (KML) outputs. Hausa romance novels covers women live issues such as love stories, marital life story, polygamy, early marriage and problem of force marriages etc (Adamu 153; Furniss 23; Sabe 13). The romance works attracted the attention of educated elites from the academic, journalist and also religious scholars attacking and accusing the 
readership, readers as well as the content of the novel for being inculcated/corrupting the minds of young girls of Western notions which is against the tradition and teaching of Hausa Islamic society.

The main aim of the romance authors was to entertain its female readers even though it seems to occupy the lower shelf in the literary system in comparison with other global popular romance genres. Yet there is little attention given about reading practices that goes with readers view and ideas that accompany its value through their interpretive process itself. This study was carried out to understand more about the process of literary interpretation of the Hausa romance novels using the Transactional Readers-Response criticisms of Rosenblatt (1978) as a tool to explore the reading experiences from real female readers of Hausa romance novels written in one of second major African languages after Swahili.

However, Contemporary romance books are mainstream since this strict nature of the sentiment story permits them to accomplish the profound work of the generally young women who read them, connecting with reader's reparation dreams of recuperating concerning male-female relations. Romance genre helps female readers manage a confusing relationship toward men in a culture actually set apart by male centric society and the dangers of patriarchal treatments. The purpose of the study is to argue that Hausa romance novels play a significant role in the transformation of African traditional society that treats women as weak and second class citizen.

\section{Applying the Reader-Response Criticism as a Method}

For the purposes of this study, the term transaction is used in the sense introduced by Rosenblatt (1978), who describes the reading of literature as a dynamic process in which the reader and text are part of an event, rather than separate entities acting upon each other. As part of this literary discussion, female readers are continuously trying to make sense of the work through various reasoning processes after their interaction with the literary text they read at a particular time or contexts for leisure and entertainment. Reader-response criticism is a literary critical theory developed and promoted by a variety of literary theorists and critics. Depending on the person advancing the concept, the theory may take on any subjective meanings. Generally, reader response criticism suggests that a text gains meaning by the purposeful act of a reader's reading and interpreting it. The relationship between the reader and the text is highly recognized; the text does not exist without a role played by the reader (Cai 220; Ghandehari 1388; Oatley 454). Any given text sitting on a shelf or its self does nothing unless a reader evokes on it and interprets his/her experiences. It was also discovered that any text itself does not come alive until the reader and text are joined. The notion of reader-response theory concentrates on the role of a reader in determining the meaning (Rosenblatt, 1994). 


\section{The Role of Reader-Response Criticism for the Interpretive Process}

Numerous studies on reading literature that employed the reader-response theory focuses mainly in the classroom contexts (e.g., Cai 220; Iskhak 18; Mart 87). Thus, this study suggests the complexity of the literary interpretive process and indicates that the individual readers can become more interpretive with regards to applying their views and ideas to the literary texts.

Participants:

Table 1: The Pseudonym of the Female readers

\begin{tabular}{|c|c|c|c|}
\hline S/N & Names & Qualification & Year of Reading Experience \\
\hline 1 & Aisha & NCE & 6 \\
\hline 2 & Sumayya & NCE & 5 \\
\hline 3 & Zulaihat & NCE & 7 \\
\hline 4 & Khadijat & NCE & 5 \\
\hline 5 & Zuwaira & ND & 6 \\
\hline 6 & Bilkisu & ND & 6 \\
\hline 7 & Ummulkhair & ND & 5 \\
\hline
\end{tabular}

Source: Author

The study was conducted with (7) female readers selected from two book clubs in the Kano state in northern Nigeria. Therefore, four female participants have acquired the National Certificate in Education (NCE), while 3 obtained a National Diploma (ND). They have 5-7 years reading experiences, while the remaining four readers were chosen and participated voluntarily which has only three years of reading practices of the romance novels.

\section{The Interviews}

To gather baseline data on interpretive processes and beliefs of the female reader's experiences, each of the eight readers was interviewed once after the other. The researcher met with each student individually for one to two hours. During the first stage of the interview, the female readers were asked for general questions about their interpretive beliefs, processes, and experiences: This study views them generally as female readers and literary critics of interpreting a story. The readers were asked to think critically while reading and interpreting a story. However, critics of romance novels such as Radway and Fordham have argued that as long as subjects report information they would normally notice while doing the task. All interviews were tape-recorded and transcribed. 


\section{Reviews of Related Studies}

Schieble has contributed toward a better appreciation to the extent and how reader response theory applied in teaching reading to adolescent pre-service teachers posit their reading experiences and voices on the two stances: i.e. aesthetic and efferent(384). The finding shows that the majority of the students responded on the aesthetic reading stances with the text than efferent stances. Park conduced a similar study of pre-service teachers for the development of their literacy skills using literature in the classroom context (384). The researcher used content documents of three years and teachers writing and responses. The finding shows that using literacy to enhance the supervisors, teachers and adult learners' skills, literacy and communicative competence. Solanke pedagogical and bibliographical used as a methodological framework for examining the role of African and Nigerian literatures for a long time (290). The study highlights the twentieth century of Onitsha Market Literature in eastern Nigeria and described different categories of novellas, pamphlets, novellas, and chapbooks distributed to the readers for leisure and entertainment of the in popular fictional literary writing in West African Literature.

Iskhak described the significance of the application of Rosenblatt's readerresponse theory for teaching literature to the EFL students in Indonesia (18). The researchers used a purposive sampling technique for the participant's selection and adopted Beach and Marshall's (1991) seven types of strategies: engaging, describing, conceiving, explaining, connecting, interpreting, and judging to enhance the students' interpretive process when reading a literary text at different contexts. Their results show the students' improvements in terms of freedom of expressions on their personal understanding and self-confidence during learning activities which helped them to enhance their and linguistic ability.

For their part, Friatin, et al. explored the impacts of Reader-response to teach literature in the classroom context for male and female students of EFL understudy instructors' stylish encounters in interpreting different reactions and ideas (167). The study is supported by Rosenblatt's (2005). Data were collected through classroom observation, documented, written journals and questionnaires. Their findings revealed that female subjects of the two groups used more expressive strategies than male did. Finally, they suggested that further studies should focus on other responses and expressions from both male and female. Similarly, Ishak et al. investigated the effects of reader response approach Rosenblatt's to enhance the students' performance in analyzing and judging the literature reading in the classroom (18). The researchers employed a mixed method for their data collection and also used ANOVA for the analysis. The study recommends further studies to develop reader response-based literature teaching model across contexts in reference to gender issues as well.

However, there are other studies conducted on romance novels for example: Roach discusses the impact of romance novels as the most powerful narrative tool that attracted most women in Western countries popular culture which originated its roots in 
Christianity (15). The study further explains that romance stories and operating as a mythic story in relation to human nature and living on earth, which focuses mainly on the themes of happily ever after at the end of most romance genres. Similarly, Kramer pointed out that the human body is a cultural text, and can be considered as a way of enlightenment and resisted different forms of social inequalities to very society (23). The study explains the role of heroines experiencing various forms of oppression and confronting traditional patriarchal notions about femininity that position women as objects for sex. Finally, Kramer discusses the significance of using female characters in most romance novels to establish their social and feminist ideology beyond the primitive thinking (23). In another study, Sheehan and Stevens examined the role of romance novel distribution in some academic libraries in the USA. The study concluded that reading romance novels contributed towards the development of researchers and students for leisure reading, scholarly study and incorporating into the curriculum at higher education and university for teaching English language courses (Sheehan and Stevens 23). Similarly, Fletcher and Kloester also discusses how the academician incorporated popular romance novel for teaching English language for undergraduate in the University of Tasmania students theoretical frameworks for interrogating the compounded and disputed relationship between fiction and history to enhance their reading skills(11).

\section{Analysis and Results}

The findings of this study are reported in four sections: the first is the analysis of the variations of interpretive ideas on the value of the romance novels, between the interactions in their reading practices at weekend reading club discussions. The second part, the analysis of their responses which challenged the assertion made by the literary critics underrates the contents and reading habits of the female readers. Third part, the analysis of their preference of showing the struggle and resistance of the traditional marriage system in the society. Fourth part, showing the individual ideas on the balancing the female social inequality from the romance genres.

In order to examine the ways in which variations in the participation of the Hausa female readers in the interpretive process might have influenced their readership processes, values and ideas, it's necessary to identify their differences in view. Three themes emerged from the interviews: (i) promoting literacy development (ii) resistance against the traditional marriage system in the society (iii) enlightening to the female on social inequality under African patriarchal traditions.

\section{Promoting Literacy Development}

Therefore, the role of author in providing reading material in Hausa popular romance novels is not new because the women readers have read the text and understood the content of the story from the beginning up to the end of it. All (7) female expressed their ideas and preferences during the interviews and interactive sessions on 
their reading experiences. For instance, Aisha, one of the female readers, shared her views as if follows:

I am reading the Hausa romance novels for quite a number of years, but regarding my best themes are many. Sometimes If I feel to read a novel written on certain issues I made my selection based on the novel title and author popularity. As a reader, I challenged the primitive notion of critics who underrate the readership of romance novels. (Interview)

Similarly, Sumayya remarked:

From my understanding as I have experience of 5 years reading these types of literary texts, every reader has her own choice and interest, I liked to read a novel written about promoting literacy development; I like a story where the heroine was supported to attend a school and acquire higher qualification to get a job and become self-reliant. Therefore, there is a need for every woman to be empowered to avert illiteracy and reduce poverty in our traditional African society. (Interview)

In addition to that, Zulaihat pointed out:

I like to read a story with themes focusing on supporting women's education were a female characters struggle to attend school and to be educated woman. I also got the courage and zeal to read more stories to enhance my reading proficiency. It improves my imaginative thinking, to have equal opportunity with men in relation to socio-political appointment in every sphere of human life. (Interview)

By examining the choices made by the above female readers, it is clear that "literature concerns the soul, each person has a distinctive soul that cannot be totally identical" (qtd. in Van 3). Several studies revealed that Transactional Reader-Response Theory has been considered as an effective approach to engage readers in reading and responding literature (Chou 181; Liaw 44). Applying the theory in this current study explored the reading experience from the perspectives of female readers of the Hausa romance novels, which enable them to express their feelings, views and ideas on their favorite themes. 


\section{Resisting against the Traditional Marriage System in the Society}

Khadijat responded:

Well, to me as a reader of these romance novels, the plot really helps us to learn many things, for instance, there are themes of love relationship between the heroine and her proposed man to marry. I like to trace their relationship until it lasts up to the level of making engagement. Secondly, at the end of the story they got married and begin their new life as husband and wife. I feel like I am the one reaching that level of becoming a full house wife. (Interview)

\section{Public Enlightenment to the Female on Social Inequality}

Well, every reader is aware that Hausa romance novels focus on entertaining the audience especially women. Though, as a reader of this literary works when Zuwaira also expressed the view for associating herself against the primitive marital system in Hausa society which young girl has no right to choose whom she will marry. Zuwaira She said:

As a reader of Hausa romance novels, I like to read a story written to enlighten against the primitive marriage system in our society that a girl doesn't have right to choose her husband. This problem affected the lives of many young girls. Some run away from home and become prostitutes as a result of arranged/forced marriage. Some young girls jump into rivers to commit suicide and end their lives instead of living in terrible situations with an unwanted husband. (Interview)

This assertion goes in line with Bun (2007) who argues that romance novels serve as a tool for women with the opportunity to experience care and attention to be given to their spouse when getting married and fulfill their psychological needs of joy and happiness in their lives. Furthermore, Bilkisu expresses her concern on personal understanding stories. She Said:

As a reader of this novels, it contains so many themes but, I really enjoyed the stories that concentrate on enlightening women the importance of neatness as well as educating them on how make various dishes to please her husband. Also, reading the novels broadened my knowledge and developed my reading literacy. (Interview) 
Examining the responses of female readers individually revealed a complex interrelationship of their interpretive experiences, beliefs, and experiences. Each female reader had particular perspectives to the process of literary interpretation. Literary scholars and researchers described the role of literature as the reflection of the society, it is a fact that has been acknowledged globally (Duhan, 34; Felski, 2011). It is clear that literature reflects the nature, attitudes, traditions and cultures of every society. Literature also conveys the virtues in the society by means of imitating human activity with a view to guide people to emulate them so that virtue may persist. In every literature we come across stories that portray human life through the roles of some characters' action to convey certain messages for the purpose of instruction, information and entertainments. Every writer is a part of the society to which he belongs (Radway 78; Regis 13). This assertion is in line with main goal of the Hausa romance novels which play a significant in the social transformation against the African patriarchal structures and enlighten females to be empowered by increasing exposure through acquiring formal education. They will no longer be ignorant of their rights but challenge inequality to better life and fulfillment.

\section{Conclusion}

This study examined the literary interpretive processes of adolescent female readers in the context of their beliefs about interpretation and their instructional experiences in literature. The interpretive process was conceptualized as a complex intertextual transaction that is related to readers' interpretive beliefs and experiences. Consistent with other studies of adolescent responses to romance readers (e.g., Duhan, 34;.Modleski, 2008), the processes of the female readers in this study can be described as fairly interpreted in terms of their reasoning operations and fairly textual in terms of their inferences. In this study an attempt was made to create variations in the existing interpretive communities of Hausa romance novel readers. However, the shift in the intertextuality of their interpretive processes varied by individual. That is, in reading complex literary works, these female tended to express their personal understanding and ideas were analyseand draw our conclusions aboutto some extent on the texture of the stories. Relatively few of their inferences were related to extra textual sources of information, such as information related to the author, other works of literature, or their own personal reactions, although in this studies are in line with (Becker, 126: Many 186), a relationship has been found between personal response and thematic generalizations and story evaluation. The conclusion should clearly state the major findings of the paper without much repetition.

\section{Works Cited}

Adamu, Abdalla Uba. "Idols of the marketplace: literary history, literary criticism and 
the contemporary Hausa novel." New Nigerian Weekly, 1999, pp. 12.

Adamu, Abdalla Uba. "Loud bubbles from a silent brook: Trends and tendencies in contemporary Hausa prose writing." Research in African Literatures 2006, pp. 133-153.

Cai, Mingshui. "Transactional theory and the study of multicultural literature." Language Arts, vol. 85, no.3, 2008, pp. 212-220.

Chou, I-Chia. "Engaging EFL students in e-books using reader-response theory." The Reading Matrix: An International Online Journal. WenzoUrsuline University of Languages (2015).

Becker, Ruth R. "Reader response: Students develop text understanding." Reading Horizons: A Journal of Literacy and Language Arts, vol, 40. no. 2, 1999, pp. 103126.

Buba, Malami. "SaKo: The message of love and associated concepts in the documentation of Hausa popular literature." Asian Journal of African Studies vol. 45, 2019, pp. 77-103.

Bun, Jennifer C., and Jonathan M. Bowman. "The Effects of Romance Novel Readership on Relationship Beliefs, Romantic Ideals, and Relational Satisfaction." basılmamışdoktoratezi, Boston College.2007.

Duhan, Roshni. "The Relationship between Literature and Society." Language in India vol. 15, no.4, 2015. pp, 192-202.

Duhan, Roshni. "Role of Women Novelists and Feminist Criticism in English Literature with Special Reference to Toni Morrison's the Bluest Eyes." International Journal Advances in Social Science and Humanities, vol.3, Issue 03, 2018. pp. 29-34.

Felski, R. "Uses of literature. Blackwell Publishing Limited. vol. 71." 2011.

Fletcher, L. M., R. S. Gaby, and Jennifer Kloester. "Embedding Popular Romance Studies in Undergraduate English Units: Teaching Georgette Heyer's Sylvester." Journal of Popular Romance Studies vol.1.no 2 2011.pp 1-11.

FordHam, Helen. "'That's love for you': destabilizing divides and re-imaging subjectivities in the romantic fiction of eloisa James." Australasian Journal of Popular Culture vol.3, no.3, 2014, pp. 273-284.

Friatin, Lilies Youlia, Iskhak Said, and EtikaRachmawati. "Male and Female EFL Student Teachers' Aesthetic Experiences of Reading and Responding to Literary Works." The 63rd TEFLIN International Conference, 2016, pp.162-167.

Furniss, Graham. "Documenting Kano 'Market'Literature." Africa Bibliography 2000, pp. vii-xxiii.

Furniss, Graham. Hausa popular literature and video film: the rapid rise of cultural production in times of economic decline. Inst. fürEthnologie und Afrikastudien, 2003, pp.1-14.

Furniss, Graham, and Abdalla Uba Adamu. "“Go by appearances at your peril”: The Raina Kama Writers' Association in Kano, Nigeria, Carving out a Place for the "Popular" in the Hausa Literary Landscape." Research in African Literatures vol.43, no.4, 2012, pp. 88-111.

Ghandehari, Shaghayegh. "Definition of reader, as a relative concept, in reader-response theories." Procedia-Social and Behavioral Sciences, vol. 70, 2013, pp. 13811388.

Ishak, Aryanti, and ZaidahZainal. "Learners' Use of Efferent, Aesthetic and Critical Stances When Reading a Novel." LSP International Journal, vol. 6, no.1, 2019, pp, 1-18. 
Kramer, Kyra. "Getting Laid, Getting Old, and Getting Fed: The Cultural Resistance of Jennifer Crusie's Romance Heroines." Journal of Popular Romance Studies vol.2.no, 2, 2012,pp.1-23

Larkin, Brian. "Indian films and Nigerian lovers: media and the creation of parallel modernities." Africa. 1997, pp. 406-440.

Liaw, Meei-Ling. "Exploring literary responses in an EFL classroom." Foreign Language Annals vol. 34.no, 2001,pp.35-44.

Malumfashi, Ibrahim AM. "The Hausa Writer, The Publisher, The Distributor and The Readership Culture: An Overview." Reading empowers: proceedings of the workshop: encouraging free speech, promoting the reading culture: held in Kaduna, Promote Reading Culture, 1997. pp.44.

Many, Joyce E., et al. "Transactional criticism and aesthetic literary experiences: Examining complex responses in light of the teacher's purpose." Reading Horizons: A Journal of Literacy and Language Arts vol. 36, no.2, 1995, pp, 167186.

Mart, CagriTugrul. "Reader-response theory and literature discussions: A Springboard for exploring literary texts." StanisławJuszczyk vol. 78, 2019, pp 79-87.

Modleski, Tania. Loving with a vengeance: Mass produced fantasies for women. Routledge, 2008.

Radway, Janice A. "Women read the romance: The interaction of text and context." Feminist studies, vol, 9, no.1, 1983, pp. 53-78.

Park, Jie Y. "All the ways of reading literature: Pre-service English teachers' perspectives on disciplinary literacy." English Education vol. 45, no.4, 2013, pp. 361-384.

Oatley, Keith. "Meetings of minds: Dialogue, sympathy, and identification, in reading fiction." Poetics, vol, 26.5-6, 1999, pp. 439-454.

Regis, Pamela. "What do critics owe the romance? Keynote address at the second annual conference of the international association for the study of popular romance." Journal of Popular Romance Studies, 2011. Pp.1-13.

Roach, Catherine. "Getting a good man to love: Popular romance fiction and the problem of patriarchy." Journal of Popular Romance Studies 2010, pp.1-15.

Rosenblatt, L. M. (1978). The reader, the text, the poem: The transactional theory of the literary work: Southern Illinois University Press.

Rosenblatt, Louise M. "The transactional theory of reading and writing." 1994.

Sabe, Bashir Abu. "Developmental Views of Kano Market Literature towards Societal Change." a paper presented at the International Conference on Africa New Perspective held at Institute of African Research and Studies, Cairo University, Egypt. 2016, pp.1-13.

Schieble, Melissa B. "Reading between the lines of reader response: Constructing 'the other' through the aesthetic stance." Changing English, vol, no. 17.4, 2010, pp. 375-384.

Sheehan, Sarah, and Jen Stevens. "Creating a popular romance collection in an academic library." Journal of Popular Romance Studies 2015, pp. 1-23.

Solanke, Stephen O. "Exploring and Bibliographing the Nigerian Onitsha Market Literature as Popular Fiction." International Journal of English Literature and Culture, vol. 2, no. 11, 2014, pp. 277-290. 


\section{The Author}

\section{Haruna Alkasim Kiyawa}

School of Secondary Education (Languages), Jigawa State College of Education, PMB 1002 Gumel, Nigeria.

\section{Email: kiyawaharuna@gmail.com}

\section{The Article}

Date Sent: 18/11/2020

Date Revised: 07/01/2021

Date Accepted: 12/01/2021 